\title{
HOUSE-BUILDING ANALYSIS WHEN USING ADDITIVE TECHNOLOGIES:CLASSIFICATION, ADVANTAGES AND DISADVANTAGES
}

\author{
Ekatarina Gennadievna Pahomova ${ }^{1 *}$, Pavel Vladislavovich Monastyrev ${ }^{2}$, Elena Sergeevna Mishchenko ${ }^{2}$, \\ Valery Alexandrovich Yezerskiy³, Ivan Aleksandrovich Ivanov², Azaoui Doubla Balthazar ${ }^{2}$ \\ ${ }^{1}$ Southwest State University, Kursk, Russian Federation \\ ${ }^{2}$ Tambov State Technical University, Russian Federation \\ ${ }^{3}$ Bialystok University of Technology, Poland
}

The construction industry is evolving in the field of development and implementation of an information modeling approach for buildings. At present, digital building models are being transferred to the construction industry, where $3 D$ printers are used to erect buildings. By extrusion they apply concrete mixture layer by layer along the limit contour of the building structure, thereby making building structures of the building or "printing" the building.

The article discusses the principle of construction when using additive technologies. It also analyzes the existing technologies for "printing" buildings and it considers the advantages and disadvantages of this technology. Besides, the work gives a classification of building technologies and the exterior walls of the constructed buildings using 3D printers.

Key words: information and digital technologies, 3d construction printer, additive technology, extrusion, construction industry

\section{INTRODUCTION}

In recent years, the innovative orientation of the economic development of the Russian Federation has increasingly taken a bias "towards digitalization". This trend fully applies to the construction industry, which since the beginning of the century has been moving towards the development and implementation of an information modeling approach for buildings [1, 2, 3, 4, 5]. At present, the digital building models are being transferred to the construction industry, where 3D printers are used in the construction of buildings. By extrusion they apply concrete mixture layer by layer along the limit contour of the building structure, thereby making building structures of the building or "printing" the building. You can meet the following terms characterizing this technology: 3D-printing of the building; building construction using a 3D construction printer; building construction using an additive technology; building construction using a method of extrusion.

\section{MATERIALS AND METHODS}

In China the technologies of building construction using $3 \mathrm{D}$ printers were actively developed and the "printed" residential buildings using a 3D printer first appeared in 2014 [6]. These houses were built in Shanghai by Shanghai WinSun Decoration Design Engineering Co (WinSun). Each building has an area of $200 \mathrm{~m}^{2}$; it took 24 hours to "print" it (Fig. 1). The building consists of individual modules, which were "printed" by a 3D printer and mounted on a construction site into an entity. The wall section is a triangular shear wall between two con- crete walls. The hollow parts were used to fill with the foam insulation. A concrete mixture was used to "print" modules. The technogenic wastes were used to prepare this mix [6].

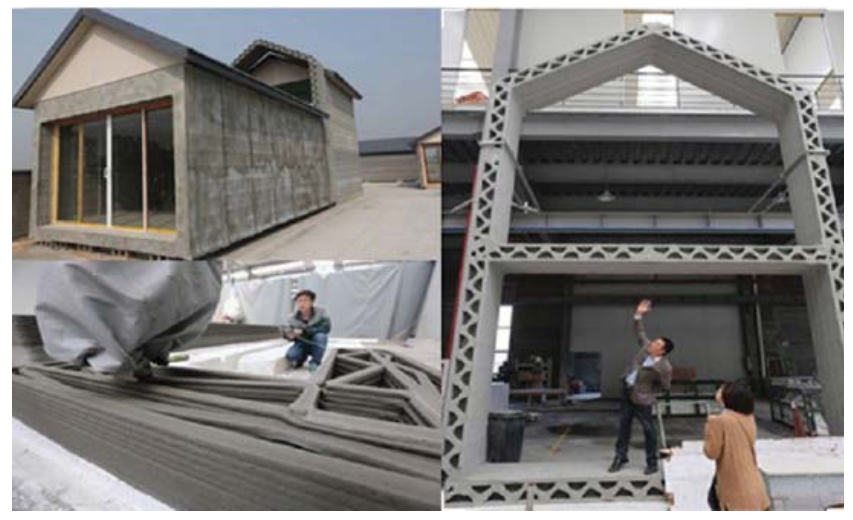

Figure 1: WinSun building and wall construction (China, 2014) [6]

One year later, Chinese engineers simultaneously presented 2 projects at an exhibition in the industrial park in Suzhou, in Jiang Province: a five-story residential building, which is considered to be the tallest building constructed using 3D printing technology and a two-story villa with an area of $1100 \mathrm{~m}^{2}$ [7]. Both buildings consisted of individual modules, which were manufactured at the WinSun factory and mounted on the construction site.

In China, Beijing HuaShang Tengda Industry and Trade (Huashang Tengda) is the competitor of WinSun, which uses additive technologies in construction. This company, unlike WinSun, "printed" its building for 45 days on a construction site, and not at its own production [8]. 
In the spring of 2016 in Dubai the "Office of the Future" was built under the special program of the Government of the United Arab Emirates. The construction process took 17 days. The parts of the building were "printed" at WinSun's Chinese factory as blocks and shipped to Dubai. 17 people were engaged into the assembly and decoration of the "Office of the Future" [8].

Russian engineers are also working on 3D printing technology for buildings. In the winter of 2017 in Stupino, Moscow Region, an American company "ApisCor", led by a Russian engineer Nikita Chen-Yun-Tai, presented a demonstration "printed" building using a 3D printer. This house is considered to be the first residential building in Russia, printed on a 3D printer. The work on the building took two months. The 3D printer was only operating during 20 hours, the rest of the time was devoted to an external and internal decoration. The building consists of two rooms and has a total area of $36.8 \mathrm{~m}^{2}$ (Fig. 2). When erecting they used an APIS COR printer, which was located inside the building. The frame base of both the external and internal walls consisted of concrete shells with a thickness of $25 \mathrm{~mm}$. The outer wall was a multi-chamber structure, in which the inner shell of the wall was connected with the intermediate shell by a sinusoidal concrete shear wall, and the outer shell was at some distance from the intermediate one(Fig. 2). The shells of the inner walls were interconnected by reinforcing rods with a diameter of $8 \mathrm{~mm}$. The number of reinforcing bars was taken from the calculation of at least $4 \mathrm{pcs} / \mathrm{m}^{2}$ (Fig. 2). The wall thickness depended on the strength, heat engineering and sound insulation indicators $[8,9]$.

One more domestic company, LLC SPETSAVIA, should be mentioned. It does not only develop equipment designed for 3D printing, but it also erects buildings using a $3 \mathrm{D}$ printer (Fig. 3). The printing speed of the walls was $10 \mathrm{~m}^{2}$ per hour. This company uses the following mixtures to construct buildings by the method of layer-by-layer extrusion: kaolinic; glass-fiber reinforced; cement with mineral additives, finely dispersed cement; high strength cement [10].

A technique analysis of a house building using 3D construction printers revealed the advantages and disadvantages of these technologies. This analysis also made

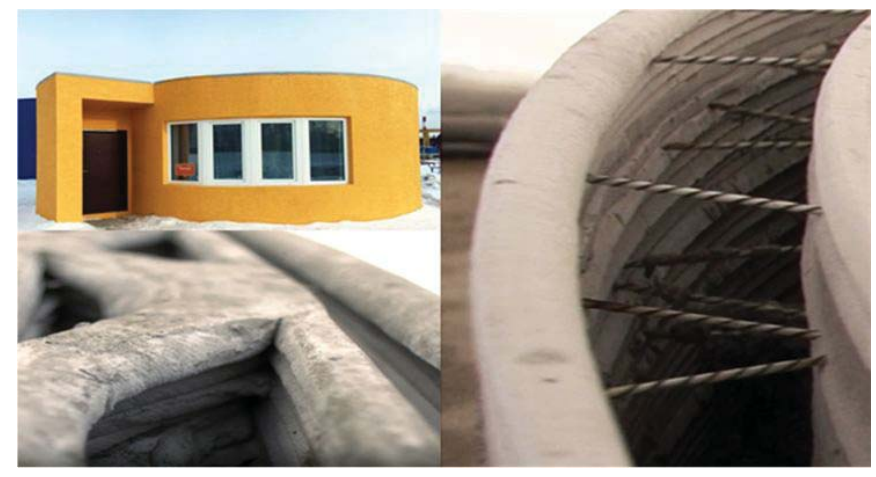

Figure 2: Demonstration building in Stupino and the construction of its walls (Russia, 2017) [8,9]
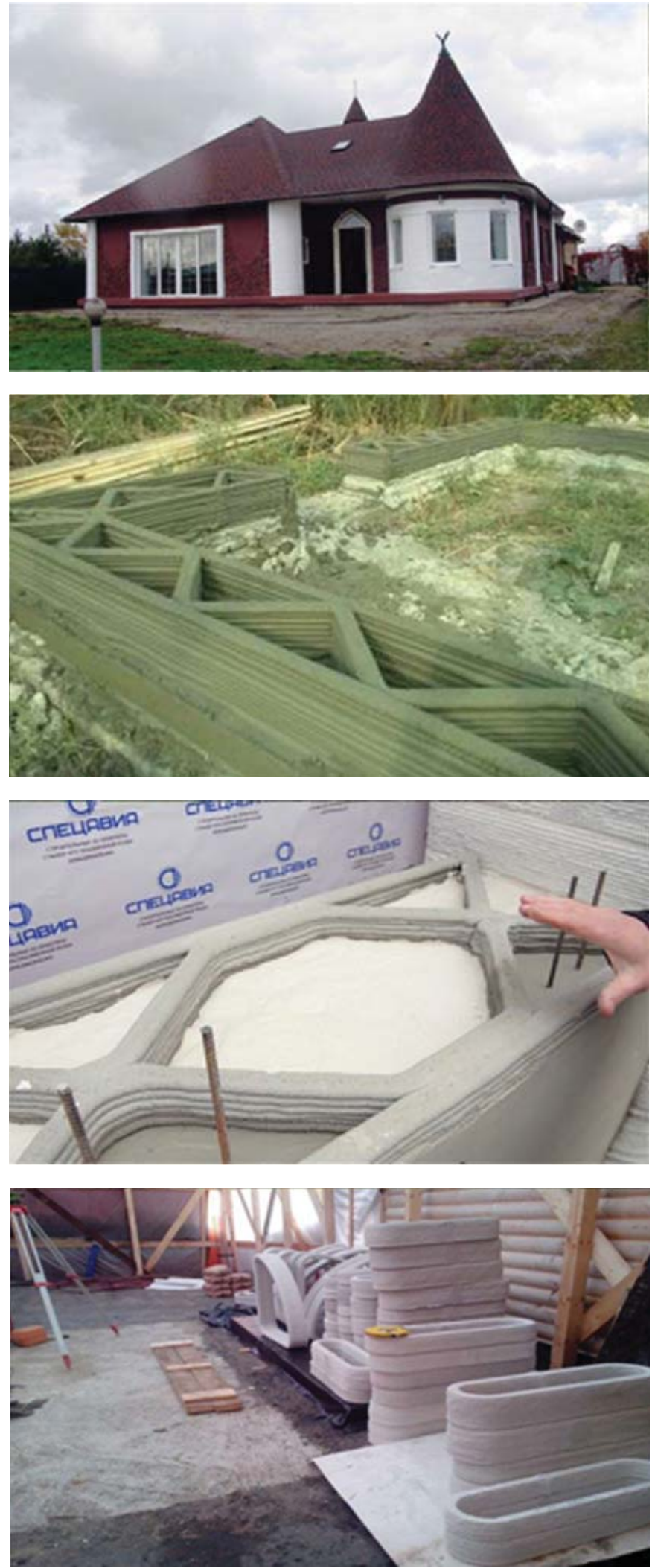

Figure 3: Building and design concepts of the walls by the company LLC "SPETSAVIA" (Russia, 2018) [10]

it possible to develop a classification of building technologies using a 3D printer, and a classification of the exterior walls of a constructed building using 3D printers. 


\section{RESULTS}

Advantages and disadvantages of 3D printing technology for buildings are shown in Table 1. Technological advantages of using 3D printing for buildings are associated with high rate of the building construction, low labor costs, unlimited architectural solutions, a significant reduction of facility completion deadline, equipment mobility, free choice of wall thickness and its configuration, lack of formwork, high precision of structure fabrication, the ability to work in a tight working space. From an economic point of view, the advantages of 3D printing of buildings include the fact that the use of these technologies can significantly reduce the cost of building construction. Ecological advantages include reducing the negative impact on the environment by reducing construction wastes and a short period of construction work. Besides it enables to use building materials, the production of which uses technological waste (structural and heat-insulating materials). Another significant advantage is the social importance of using 3D printers, in other words per square meter market price of housing is reduced, and the construction process ensures high labor safety.

Despite the fact that the use of $3 \mathrm{D}$ printers in construction is predicted by the enormous prospects, at the moment there are many questions regarding the technology of building construction itself, for example: lack of a regulatory framework and qualified specialists; the complexity of concrete proportioning and its high cost; the complexity of "printing" horizontal structures (floor panels, etc.) in the final position; technological breaks. Among other disadvantages we can also highlight the following examples: back- log in the rate of the related

Table 1: Advantages and disadvantages of 3D printing technology of buildings

\begin{tabular}{|c|c|c|}
\hline Criteria & Advantages & Disadvantages \\
\hline Technological & $\begin{array}{l}\text { - } \text { High rate of building } \\
\text { - } \text { Low labor costs } \\
\text { - } \text { Unlimited architectural solutions } \\
\text { deadline } \\
\text { - Equipment mobility } \\
\text { - } \quad \text { Free choice of wall thickness and its } \\
\text { configuration } \\
\text { - Lack of formwork } \\
\text { - } \quad \text { High precision of structure fabrication } \\
\text { - } \quad \text { Ability to work in tight working space. }\end{array}$ & $\begin{array}{l}\text { - } \quad \text { Lack of regulatory framework } \\
\text { - } \quad \text { Cack of qualified specialists } \\
\text { - } \quad \text { The complexity of concrete proportioning of "printing" horizontal struc- } \\
\text { - } \quad \text { tures (floor panels, etc.) in the final position } \\
\text { - } \quad \text { Back- log in the rate of the related construc- } \\
\text { tion works } \\
\text { - } \quad \text { Special requirements for the construction site } \\
\text { - } \quad \text { Operation complexity of a 3D printer at low } \\
\text { - } \quad \text { Lack of a clear methodology for reinforcing } \\
\text { structures } \\
\text { - } \quad \text { Limited "printing" area } \\
\text { Special conditions to ensure the normal } \\
\text { operation of the construction 3D printer } \\
\text { Transportation and setting up difficulties of a } \\
\text { 3D printer }\end{array}$ \\
\hline Economical & - Building cost reduction & $\begin{array}{l}\text { - High cost of concrete mix } \\
\text { - } \quad \text { High cost of a 3D printer and its maintenance } \\
\text { (if necessary) } \\
\text { - Additional costs for a tent protecting a con- } \\
\text { struction site from weathering }\end{array}$ \\
\hline Ecological & $\begin{array}{l}\text { - } \quad \text { Reduced construction wastes } \\
\text { - Short construction period } \\
\text { - The possibility of using building materi- } \\
\text { als, the production of which used techno- } \\
\text { logical wastes }\end{array}$ & $\begin{array}{l}\text { - Recycling of concrete residuals after flushing } \\
\text { the 3D printer system }\end{array}$ \\
\hline Social & $\begin{array}{ll}\text { - } & \text { Reduction of per square meter market } \\
\text { price of housing } \\
\text { - } & \text { High labor safety }\end{array}$ & $\begin{array}{l}\text { - Increase in the share of machine labor } \\
\text { - The existing mentality of the construction } \\
\text { organization towards traditional construction } \\
\text { technologies }\end{array}$ \\
\hline
\end{tabular}


construction works; special requirements for the construction site and additional costs for a tent protecting a construction site from weathering; lack of a clear methodology for reinforcing structures; limited "printing" area and special conditions to ensure the normal operation of the construction 3D printer; operation complexity of a 3D printer at low temperatures; transportation and setting up difficulties of a $3 D$ printer; high cost of a 3D printer and its maintenance; the need of recycling of concrete residuals after flushing the $3 \mathrm{D}$ printer system; the existing mentality of the construction organization towards traditional construction technologies.

The classification of building technologies using a 3D printer is shown in Figure 4. In this classification, the features were grouped into two groups: technological and structural-and-technological. The technological attributes include those that are directly related to the building technology and structural-and-technological ones characterize the constructive and space-planning decisions of buildings that affect the 3D printing technology.
Technological features include: the method of building construction; place of manufacture of structural elements with a 3D construction printer; type of a 3D construction printer; place of manufacturing of concrete mix.

According to the method of construction the buildings can be prefabricated, monolithic and precast-monolithic. Prefabricated buildings in this classification are the buildings that are mounted from structural elements "printed" by a $3 \mathrm{D}$ printer at a reinforced concrete plant or on the construction site near a building under construction. Monolithic ones refer to the buildings whose carrying frame is entirely "printed" by a 3D printer on the construction site. Precast- monolithic buildings are where the carrying frame partially consists of the structures "printed" by a $3 \mathrm{D}$ printer in the final position on the construction site and partially from the prefabricated elements.

According to the place of fabrication, a 3D construction printer distinguishes between structures "printed" on the construction site, at a concrete factory and combined, i.e. during the construction of the building one part of the

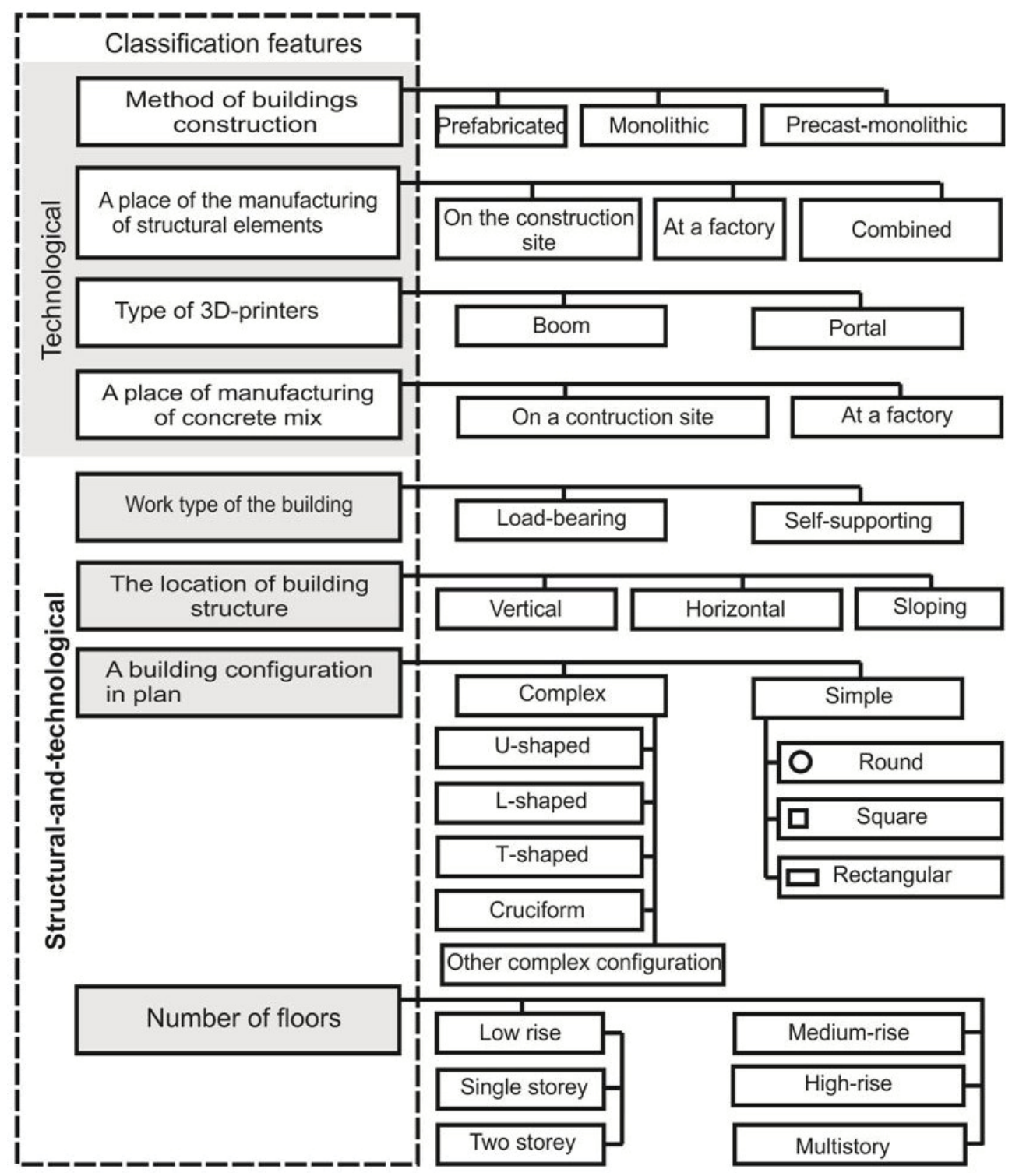

Figure 4: Classification of building technologies using a 3D printer 
structures is made on the construction site and another at a factory.

3D construction printers can be divided into two groups according to their type: boom and portal. A boom printer is a boom on the end of which there is an extruder.
Such printers are able to "print" building structures being outside the building or inside it. They are light in weight, quite mobile and easy to transport. The dimensions of the buildings under construction using such printers are limited by the radius of the boom.

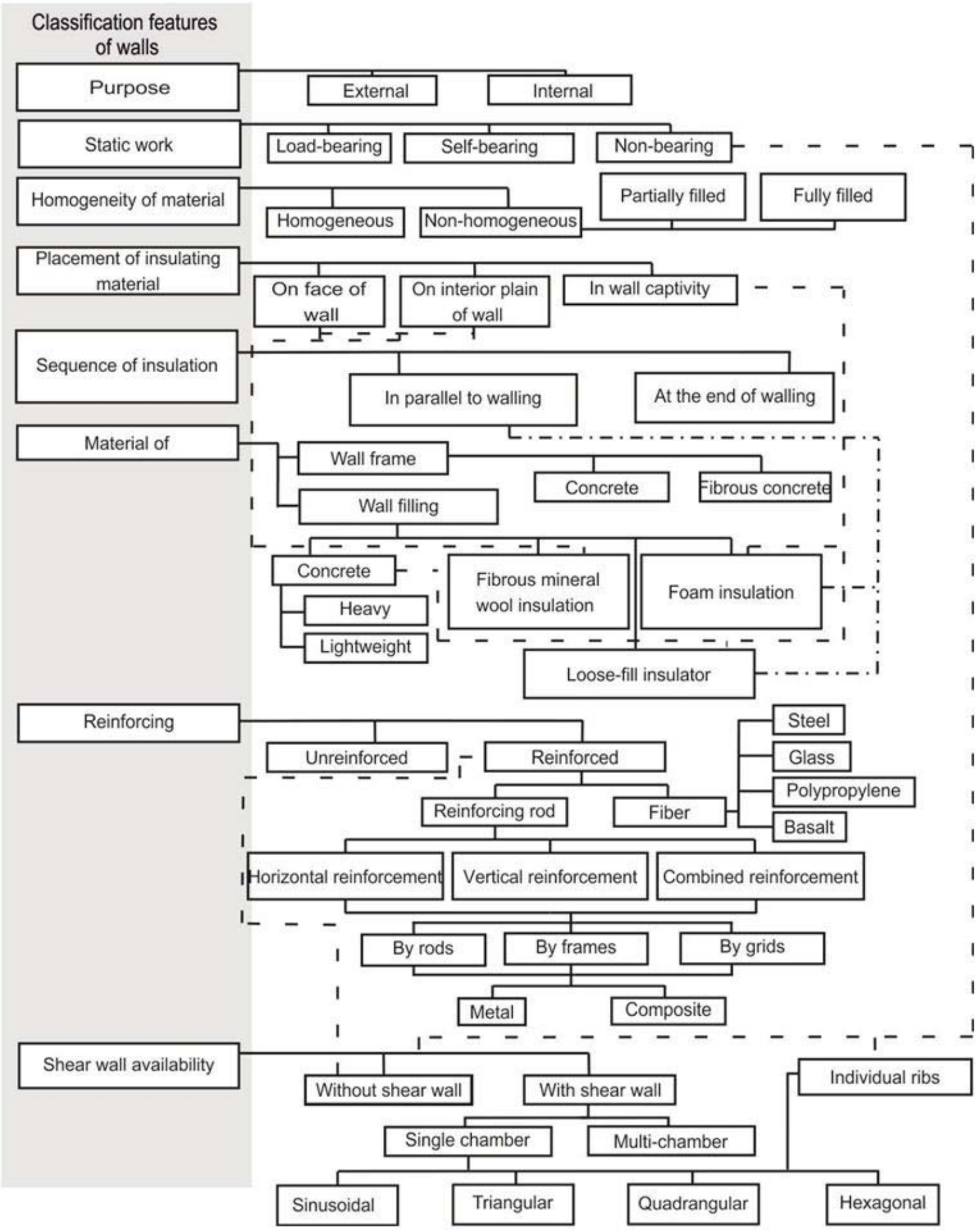

Figure 5: Classification of building walls erected using a 3D printer 
$3 \mathrm{D}$ portal printer is a mobile device in the form of an overhead crane. There is an extruder on the moving carriage there. The dimensions of such printers should be larger than the building being erected; therefore, the dimensions of the erecting building are limited in height and with to the operating area of the portal printer.

The concrete mix used in the "printing" of buildings by 3D construction printers can be prepared on the construction site or at a factory.

The structural-and-technological classification features include: the work type of the building; location of the building structure; building configuration in plan; number of floors.

The structures can be divided into load-bearing and self-supporting. Load-bearing structures are those that perceive operational loads and impacts. They provide a spatial rigidity and stability of the building. These include load-bearing walls, columns, communications, shear walls, floor elements, etc. Self-supporting structures perceive the load only from its own weight. These include such enclosing structures as parting walls, pediments, etc. According to the location building structures can be vertical (walls, columns, poles, racks, etc.), horizontal (beams, bearer, floor panels, etc.) and sloping (domes, arches, etc.).

According to the configuration the buildings in plan can be divided into simple (round, square, rectangular) and complex (U, L, T - shaped, cruciform and other complex configurations).

According to the number of floors the buildings are divided into low-rise (single-storey, two-storey), medium-rise (3 ... 5 floors), high-rise ( $6 \ldots 9$ floors), multi-story (10 ... 25 floors) and skyscraper (more than 25 floors). It should be noted that until now the additive technologies have been used in the construction of low and medium-rise buildings. However, with the development of technology 3D printers will be used in the construction of buildings of higher floors, as reflected in the classification.

The walls of buildings erected using a 3D printer were classified according to the following criteria (Fig. 5): purpose, nature of statistical work, homogeneity of the material, placement of insulation, sequence of insulation, material, reinforcement, and the presence of a shear wall.

According to a designated purpose, the walls of buildings can be external and internal. External walls protect the premises from climatic influences and create an external character of the building $[6,7,8]$. Internal walls delimit the rooms and are the architect's tool for creating space planning decisions. Depending on the purpose of the walls, they must meet the structural-technological, sanitary and hygienic, operational, aesthetic and economic requirements $[11,12,13,14,15,16]$.

By the nature of the static work, the external and internal walls can be load-bearing, self-supporting and non-bearing. At present when using $3 \mathrm{D}$ construction printers to "print" buildings, they produce load-bearing and self-supporting walls. Load-bearing walls perceive a constant load not only from their own weight, but also from floor panels (coatings) and temporary load. Self-supporting walls absorb the load from their own weight. It can be assumed that with the development of additive technologies, for some frame buildings, the wall panels will be "printed" at concrete factories and mounted on columns of the building. Such wall panels will be non-bearing.

According to the homogeneity of the material, the walls can be homogeneous, i.e. consist of one material and non-homogeneous that is to consist of several materials. Non-homogeneous walls can be partially filled that is to consist not only of several materials, but also have some air cavities. Non-homogeneous walls with full filling consist of various materials and do not have air cavities.

In a heterogeneous outer wall, the insulating material may be placed on the face of a wall, on the interior plain of a wall and into a wall cavity. The wall insulation from the outside and inside can be done at the end or on the sidelines of walling. The internal placement of the insulating material into the wall cavity is carried out in parallel to the construction of the wall frame.

According to the wall material, two structural elements should be distinguished: the wall frame and the filling of the wall. The wall frame is directly "printed" by a 3D printer using concrete mix or fiber-reinforced concrete. Depending on the design of the wall different materials can be used for filling it: heavy or lightweight concrete, heat-insulating materials in the form of fibrous mineral wool or foamed polymer insulation and infilling from various materials. It should be noted that for wall structures it is possible to use the construction nanomodified materials or materials in the production of which technogenic waste is used.

According to reinforcement the walls can be reinforced and unreinforced. Reinforcement can be carried out by fiber and reinforcement. The reinforcement can be located vertically, horizontally and combined in the form of individual rods, frames and grids. Reinforcement can be metal or composite. The fiber can be steel, glass, polypropylene or basalt.

Depending on the design solution, the frame of the "printed" walls can be with or without a shear wall (Fig. 1, 2 and 3). The shape of the shear wall can be sinusoidal, triangular, quadrangular, hexagonal or consist of individual ribs (Table 2). Shear walls can form chambers in the wall structure, which permits to distinguish such wall structures as single-chamber and multi-chamber (Table 2 ). By a single-chamber wall we mean the one in which there is at least horizontal or vertical section. It gives the following wall structure: a) the outer shell of the frame; b) an air gap or the space filled with heat-insulating or structural material; c) the inner shell of the frame (Table 2). A multi-chamber wall is a wall in all sections of which between the outer and inner shell of the frame there is an intermediate shell of the frame or a shear wall. 
Table 2: 3D Wall Options for Buildings

\begin{tabular}{|c|c|c|}
\hline Shear wall & Single-chamber & Multi-chamber \\
\hline \multicolumn{3}{|c|}{ With shear wall } \\
\hline \multicolumn{3}{|l|}{ Sinusoidal } \\
\hline \multicolumn{3}{|l|}{ Triangular } \\
\hline \multicolumn{3}{|l|}{ Quadrangular } \\
\hline \multicolumn{3}{|l|}{ Hexagonal } \\
\hline \multicolumn{3}{|l|}{ Individual ribs } \\
\hline \multicolumn{3}{|c|}{ Without shear wall } \\
\hline $\begin{array}{l}\text { With flexible connector } \\
\qquad \text { (model1) }\end{array}$ & & - \\
\hline \multicolumn{3}{|l|}{$\begin{array}{l}\text { With flexible connector } \\
\qquad \text { (model } 2)\end{array}$} \\
\hline Without flexible connector & & - \\
\hline \multicolumn{3}{|l|}{ Explanation of Symbols: } \\
\hline \multicolumn{3}{|c|}{$\begin{array}{l}\square_{-} \text {- concrete or fiber-reinforced concrete } \\
\text { - metal or composite reinforcement rod }\end{array}$} \\
\hline
\end{tabular}

\section{CONCLUSIONS}

It can be stated that 3D printing technologies for buildings are currently in the formative stage not only in Russia but around the world. It could be seen at all construction phases including terminology, design, technology, equipment, building materials, etc. Despite the fact that these technologies are at the initial stage of development, they are clearly up to date. This is due to the promising advantages of using additive technologies in construction, which will rapidly develop in the era of digital technologies.
We hope that the table of advantages and disadvantages of 3D printing technology for buildings presented in this article, the classification of building construction technologies using a 3D printer, and the classification of building walls to be constructed using a 3D printer will serve as elements of the scientific formation of additive technologies in construction. 


\section{REFERENCES}

1. Акимов П.А., Чернышов Е.М., Монастырев П.В. Научные исследования и разработки Российской академии архитектуры и строительных наук: состояние, направления и перспективы развития / Материалы 4-й международной научно-практической конференции «Устойчивое развитие региона: архитектура, строительство, транспорт». Тамбов. ТГТУ. 15-16 июня 2017 года. - Изд-во Першина Р.В. С. 12-28.

2. Мищенко Е.С., Монастырев П.В., Евдокимцев О.В. Аспекты разработки образовательных программ в области ВІМ-технологий с учетом работодателей / Материалы 5-й международной научно-практической конференции «Устойчивое развитие региона: архитектура, строительство, транспорт». Тамбов. ТГТУ. 24-25 мая 2018 года. - Изд-во Першина Р.В. С. 385-392.

3. Mishchenko E.S., Monastyrev P.V., Evdokimtsev O.V. Improving the Quality of Training in Building Information Modeling. ICL 2018; Kos Island; Greece; 25 September 2018 to 28 September 2018; Код 224239. Volume 916, 2020, Pages 453-459.

4. Монастырев П.В., Езерский В.А., Иванов И.А., Азауи Дубла Б. Аддитивные технологии возведения стен малоэтажных зданий и их классификация / Фундаментальные, поисковые и прикладные исследования РАACH по научному обеспечению развития архитектуры, градостроительства и строительной отрасли Российской Федерации в 2018 году. Научные труды РААСН. Том 2. - 2019. - С. 368-378.

5. Монастырев П.В., Езерский В.А., Иванов И.А., Бальтазар А.Д. Анализ технологий 3D-печати стен малоэтажных зданий и их классификация / В сборнике: современные проблемы в строительстве: постановка задач и пути их решения. Сборник научных статей Международной научно-практической конференции. Юго-Западный государственный университет. Курск, 2019. С. 70-80.

6. http://www.winsun3d.com/En/About.

7. URL:http://unistroy.spbstu.ru/index_2017_52/3_ zykova_52.pdf. 3D-печать в строительстве.
8. URL:http://www.3dpulse.ru/news/stroitelstvo/10-zdanii-napechatannyh-na-3d-printere. 10 зданий, напечатанных на 3D-принтере.

9. URL:https://interactive-plus.ru/e-articles/432/Action432-464902.pdf. Особенности технологии строительства домов с помощью 3D-принтера.

10. URL: http://www.nappan.ru/press/news/napechatannyy-zhiloy-dom-uteplyen-pir/. Первый в России напечатанный 3D-принтером жилой дом утеплён $\mathrm{PIR}$ теплоизоляцией.

11. Mamontov, S.A., Yartsev, V.P., Monastyrev, P.V. An artificial and natural aging of wood-fiber composite // Известия высших учебных заведений. Технология текстильной промышленности. 2017. № 1 Pages 95-101.

12. Ерофеев А.В., Ярцев В.П., Монастырев П.В. Декоративно-защитные плиты для фасадной отделки зданий // Известия высших учебных заведений. Технология текстильной промышленности. 2017. № 1 (367). С. 101-104.

13. Гусев Б.В., Езерский В.А., Монастырев П.В. Теплопроводность минераловатных плит в условиях эксплуатационных воздействий // Промышленное и гражданское строительство. 2005. - № 1. - С.48-49.

14. Гусев Б.В., Езерский В.А., Монастырев П.В. Изменение линейных размеров минераловатных плит в условиях эксплуатационных воздействий // Промышленное и гражданское строительство. - 2004. - №8. - C.32-34.

15. Loganina, V.I., Uchaevaand, T.V., Monastyrev P.V. The Method to Estimate the Surface Appearance Quality of the Paint Applied to the Cement. Journal of Engineering and Applied Sciences, 2016 Volume: 11, issue 11, p.2409-2410 (DOI:10.3923/jeasci.2016.2409.2410

16. Dubrakova, K.O., Monastyrev, P.V., Klychnikov R.Y., Yezerskiy V.A. Optimization of thermal modernization of a group of buildings using simulation modeling. Journal of Applied Engineering Science Volume 17, Issue 2, 2019, Pages 192-197.

Paper submitted: 13.08.2019.

Paper accepted: 15.11.2019.

This is an open access article distributed under the CC BY-NC-ND 4.0 terms and conditions. 